\title{
Physico-chemical characteristics of the mosquito breeding water in two urban areas of Cairo Governorate, Egypt
}

\author{
M.A. Kenawy, ${ }^{1}$ S.E. Ammar, ${ }^{2}$ H.A. Abdel-Rahman' ${ }^{1}$ \\ ${ }^{1}$ Department of Entomology, Ain Shams University, Cairo; ${ }^{2}$ Biology Department, School of Science \\ and Engineering (SSE), American University (AUC), Cairo, Egypt
}

\begin{abstract}
Certain physico-chemical characteristics of mosquito breeding habitats [temperature, $\mathrm{pH}$, salinity, turbidity, dissolved oxygen (D0) and nitrite] were examined relative to the distribution of mosquito larval species in two urban areas of Cairo Governorate namely ElMuqattam (M) and Abu-Seir (A). Mean values and ranges of such characteristics for the reported mosquito species (Culex pipiens, $C x$. perexiguus, Ochlerotatus caspius, Cx. pusillus and Culiseta longiareola$t a$ ) were reported. In conclusion, based on the significant correlations of the different characteristics with the abundance of the two common larval species (Culex pipiens and $C x$. perexiguus), salinity and D0 may be considered the predictor variables associated with the immature abundance. Considering altogether mosquitoes, there is an increasing presence from planned safe (M) to unplanned unsafe (A) habitats mainly due to turbidity and nitrite.
\end{abstract}

\section{Introduction}

Twenty nine mosquito species belong to five genera (Culex, Anopheles, Culiseta, Ochlerotatus and Uranotaenia) are indigenous in

Correspondence: Mohamed A. Kenawy, Department of Entomology, Faculty of Science, Ain Shams University, Abbassia, Cairo 11566, Egypt.

Tel.: +202.24821633/24821096/24821031, Ext: 711 - Fax: +202.26839622 -

Mobile: $+2.01223540005 / 01111151554$.

E-mail: mohamedkenawy85@yahoo.com

Key words: Culicine mosquitoes, breeding habitats, physico-chemical characteristics, urban areas, Cairo, Egypt.

Received for publication: 26 Aprl 2013.

Revision received: 28 June 2013.

Accepted for publication: 5 July 2013.

(C) Copyright M.A. Kenawy et al., 2013

Licensee PAGEPress, Italy

Journal of Entomological and Acarological Research 2013; 45:e17

doi:10.4081/jear.2013.e17

This article is distributed under the terms of the Creative Commons Attribution Noncommercial License (by-nc 3.0) which permits any noncommercial use, distribution, and reproduction in any medium, provided the original author(s) and source are credited.
Egypt, of which seven species: Culex (Culex) pipiens Linnaeus, $C x$. $(C x$.) perexiguus Theobald, $C x$. (Cx.) antennatus Becker $C x$. (Barraudius) pusillus Macquart, Ochlerotatus (Ochlerotatus) caspius (Pallas), Culiseta (Allotheobaldia) longiareolata (Macquart) and Uranotaenia (Pseudoficalbia) unguiculata Edwards) are present in the urban areas of Cairo Governorate (Tawfick, 1990; Morsy et al., 2003).

Culicine mosquitoes in Egypt mainly Culex pipiens and $C X$. perexiguus are vectors of filariasis (Harb et al., 1993), Rift valley fever virus (Meegan et al, 1980), West Nile virus and several other viruses (Darwish \& Hoogstraal, 1981).

To control mosquitoes, a good knowledge and understanding of the relevant biology and ecology of the target species is of paramount importance (Seghal \& Pillai, 1970; Gimnig et al., 2001). Moreover, the knowledge of the ecological characteristics of the breeding habitats and the environmental factors affecting mosquito abundance can help in designing optimal vector control strategies (Overgaard et al., 2001)

Generally, mosquitoes breed in a wide range of habitats with different types of waters that are known to be specific for many species. The physical and chemical nature of the water probably determines the selection of the breeding sites (Seghal \& Pillai, 1970). It was reported (Piyaratnea et al., 2005) that breeding water quality is an important determinant of whether female mosquitoes will lay their eggs, and whether the resulting immature stages will successfully complete their development to the adult stage.

In Egypt, apart from comparatively little information on certain physical and chemical factors mainly temperature, $\mathrm{pH}$ and salinity relative to mosquito breeding; (Kenawy et al., 1996, 1998; Abdel-Hamid et al., 2009, 2011a, 2011b, 2011c) no additional information is available. Hence, detailed studies on the physico-chemical properties of the different types of mosquito breeding habitats in Egypt are lacking.

This study was undertaken to characterize the larval habitats of culicine mosquitoes in two urban areas of Cairo Governorate and to examine the relation of the physico-chemical factors of the breeding waters with the occurrence and abundance of particular mosquito species.

\section{Materials and methods}

\section{The study area}

The study was carried out in two localities representing different levels of urban planning in Cairo Governorate (Figure 1): El-Muqattam $\left(30^{\circ} 21^{\prime} 21^{\prime \prime}-29^{\circ} 58^{\prime} 52^{\prime \prime} \mathrm{N}\right.$ latitudes and $31^{\circ} 20^{\prime} 52^{\prime \prime}-31^{\circ} 16^{\prime} 1^{\prime \prime} \mathrm{E}$ longitudes) which is located in southeast of Cairo and Abu-Seir $\left(30^{\circ} 10^{\prime} 43^{\prime \prime}\right.$ $30^{\circ} 09^{\prime} 11^{\prime \prime} \mathrm{N}$ and $31^{\circ} 23{ }^{\prime} 56^{\prime \prime}-31^{\circ} 22$ ' $11^{\prime \prime} \mathrm{E}$ ) which is located in northeast of Cairo within El-Marg district. El-Muqattam (M) is considered as a planned area, but some parts of it are considered as unsafe because it 


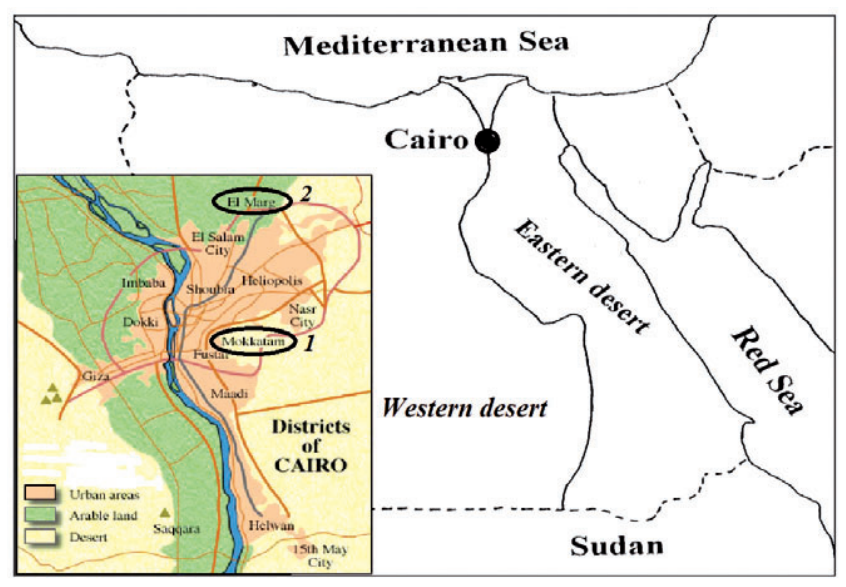

Figure 1. Location of the two study localities: El-Muqattam (1) and Abu-Seir (2) within Cairo Governorate.

lacks a piped sewage system. Abu-Seir (A) is considered as unplanned unsafe area according to the National slum upgrading policy criteria (Ammar et al., 2012). Furthermore, Abu-Seir is surrounded by agriculture lands with associated farm animals. The two localities differ in the distribution of mosquito breeding habitats: springs and spring canals (planned safe M), cesspools and cesspits (planned unsafe M) and cesspits, cesspools, drainage canals, irrigation ditches and seepage water (A).

\section{Water sampling and collection of mosquito larvae}

Water samples for physico-chemical analysis were collected (March to July 2011) from the different breeding habitats in the two localities. Samples were collected in plastic wide mouth bottles $(1000 \mathrm{~mL})$ and immediately placed in a lightproof insulated box containing ice and transported to the laboratory for analysis.

Simultaneously with water sampling, larvae were collected by dipping (WHO, 1975) using a plastic dipper, $125 \mathrm{~mm}$ in diameter with a $900 \mathrm{~mm}$ wooden handle. Collected larvae were placed in labeled plastic bags (Whirl-Pak ${ }^{\circledR} 4002$ filline, Nasco Corp., Fort Atkinson, WI, USA) and transported to the laboratory in a picnic icebox containing cold water to prevent overheating. At the laboratory, $3^{\text {rd }}$ and $4^{\text {th }}$ larval instars were identified according to the Keys of Harbach (1985) and counted. For each breeding habitat, 2-3 survey stations (each represented by 10 dips) were selected for larval collection once a month during the study period. Larval density was expressed as the number of larvae collected per dip.

\section{Water analysis}

Physico-chemical parameters (temperature, pH, salinity, turbidity, dissolved oxygen: D0 and nitrite) were determined for the seven types of mosquito breeding habitats considered in El-Muqattam (M) and Abu-Seir (A); spring, spring canal, cesspit, cesspool, drainage canal, irrigation ditch and seepage water.

The water temperature was measured in situ before the samples were collected. The water samples were analysed for $\mathrm{pH}$, salinity (\%) and dissolved oxygen (DO, mg/L) using a Horiba Water Quality Checker $\mathrm{U}-10^{\mathrm{TM}}$ (Horiba Instruments Inc., Irvine, CA, USA). The turbidity in nephelometric turbidity unit (NTU) was measured onsite using a HACH turbidimeter 2100N ${ }^{\mathrm{TM}}$ (HACH Company, Colorado, USA) while the nitrite $(\mathrm{mg} / \mathrm{L})$ was measured by a Unicam UV2-300 ${ }^{\mathrm{TM}}$ spectrophotometer (Unicam Ltd., Cambridge, UK). Analysis was carried out according to the standard methods of the American Public Health Association (APHA, 1998).

\section{Statistical analysis}

Means and Standard Deviations were calculated and compared by the one-way ANOVA. If the ANOVA shows significant inequality of the means at $\mathrm{P}=5 \%$, they were exposed to pairwise comparisons based on Tukey's honestly significant difference (HSD) test. The multiple regression analysis was applied to examine the relation of the mosquito larval densities to the physico-chemical factors of the breeding water. The slopes (regression coefficients) of the regression equations were tested for deviation from zero by t-test. The SPSS software (Version 11 for windows, SPSS Inc., Chicago, IL, USA) was used for statistical analysis.

\section{Results}

\section{Relative abundance of mosquito larvae}

A total of 3194 larvae of five species were collected from the two localities of which Culex pipiens (72.2\%), Cx. perexiguus (19.6\%) were the common species, whereas Ochlerotatus caspius (5.8\%), Cx. pusillus (2.1\%) and Culiseta longiareolata (0.3\%) were uncommon.

\section{Physico-chemical characteristics}

The compiled ranges of the determined physico-chemical parameters in the different breeding habitats were calculated for each species of mosquito larvae in the two localities. The comparative results (Table 1) show that: i) $C x$. pipiens and $C x$. perexiguus have lower temperature and $\mathrm{pH}$ ranges, higher salinity and turbidity ranges and narrower DO range in $\mathrm{M}$ than in $\mathrm{A}$; ii) Oc. caspius: has lower temperature and $\mathrm{DO}$ ranges, higher $\mathrm{pH}$, and salinity ranges in $\mathrm{M}$ than in $\mathrm{A}$, while turbidity ranges are

Table 1. Ranges of physico-chemical parameters of the mosquito breeding water in El-Muqattam and Abu-Seir.

\begin{tabular}{|c|c|c|c|c|c|c|c|}
\hline Species & Locality & Temp $\left({ }^{\circ} \mathrm{C}\right)$ & $\mathrm{pH}$ & Salinity (\%) & Turbidity (NTU) & DO (mg/L) & Nitrite (mg/L) \\
\hline \multirow[t]{2}{*}{ Cx. pipiens } & M & $17-26$ & $5.1-7.8$ & $0.62-1.21$ & $4.4-400.7$ & $3.3-7.6$ & $0-0.6$ \\
\hline & $\mathrm{A}$ & $20-30$ & $5.0-8.7$ & $0.05-0.49$ & $4.0-333.5$ & $2.1-8.7$ & 0 \\
\hline \multirow[t]{2}{*}{ Cx. perexiguus } & M & $17-26$ & $5.0-7.8$ & $0.62-1.21$ & $4.4-485.2$ & $2.8-7.6$ & $0-0.6$ \\
\hline & A & $20-30$ & $5.0-8.7$ & $0.05-0.49$ & $4.0-333.5$ & $2.1-8.7$ & $0-25.0$ \\
\hline CX.pusillus & A & $20-30$ & $5.0-5.5$ & $0.05-0.49$ & $21.9-333.5$ & $2.1-5.1$ & $0-25.0$ \\
\hline \multirow[t]{2}{*}{ Oc. caspius } & M & $17-23$ & $7.7-7.8$ & $0.95-1.21$ & $4.4-5.4$ & $6.9-7.6$ & $0-0.6$ \\
\hline & A & $22-30$ & $6.8-7.0$ & $0.05-0.09$ & $4.0-5.1$ & $7.4-8.7$ & 0 \\
\hline Cs. longiareolata & M & $17-23$ & $7.7-7.8$ & $0.95-1.21$ & 4.4-5.4 & $6.9-7.6$ & $0-0.6$ \\
\hline
\end{tabular}

DO, dissolved oxygen; M, El-Muqattam; A, Abu-Seir. 
nearly similar in the two localities; iii) $C X$. pipiens and Oc. caspius breed in water free of nitrite in A, while in M breeding water has $0-0.6 \mathrm{mg} / \mathrm{L}$; iv) $C x$. perexiguus has a lower nitrite range $(0.0-0.6 \mathrm{mg} / \mathrm{L})$ in $\mathrm{M}$ than in $\mathrm{A}(0-$ $25.0 \mathrm{mg} / \mathrm{L}$ ); v) $C x$. pusillus present only in A and Cs. longiareolata present only in $\mathrm{M}$ with different ranges.

Comparison of the mean values for such parameters (Table 2) revealed that in $\mathrm{M}$, significantly higher means of temperature in cesspools, $\mathrm{pH}$, salinity and DO in springs and spring canals and turbidity in cesspits and cesspools. Insignificantly higher mean of nitrite ( $\mathrm{P}>0.05)$ was observed in springs. In A, significantly higher means of $\mathrm{pH}$ in irrigation ditches and seepage water, salinity in seepage water, turbidity in cesspits and DO in irrigation ditches. Higher means $(\mathrm{P}>0.05)$ of temperature and nitrite were recorded in cesspools than in the other habitats.

Means for the different breeding habitats were compiled and compared to detect any difference between the two localities and results (Table 3) revealed that: i) significantly lower temperature and higher $\mathrm{pH}$, salinity and DO in planned safe area (M) than in unsafe areas whether planned in $\mathrm{M}$ or unplanned in A; ii) significantly higher turbidity in planned unsafe area (M) than in planned safe in $\mathrm{M}$ or unplanned unsafe in $\mathrm{A}$; iii) insignificantly different $(\mathrm{P}>0.05)$ means of nitrite in the three areas; and iv) considering altogether mosquitoes, there is an increasing presence from planned safe to unplanned unsafe habitats mainly due to turbidity and nitrite.

\section{Effect of physico-chemical factors on larval densities}

Multiple regression analysis for the effect of physico-chemical factors on densities of the two common species (Table 4) revealed that densities of both $C x$. pipiens and $C x$. perexiguus in the two localities were directly related to temp, $\mathrm{pH}, \mathrm{DO}$ and nitrite but were indirectly related to salinity and turbidity.

\section{Discussion}

The different breeding habitats in the two localities showed difference in their physico-chemical characteristics

Mosquito immature stages are poikilothermic and therefore, their activity depends to a large extent on the temperature of the water they inhabit. Besides nutrition, temperature is the main factor that affects the development and growth of mosquito larvae (White, 1974). In general, an increase in water temperature will result in faster development of aquatic stages, but will decrease the size of the emerging adults (Bayoh \& Lindsay, 2003) and at higher temperatures fewer adults are produced due to increased mortality (Bayoh \& Lindsay, 2004). WHO (1975) stated that the average optimum temperature for development of most mosquito species is around $25-27^{\circ} \mathrm{C}$. In the present study, a temperature range of $17-30^{\circ} \mathrm{C}$ was observed for the five reported species. In the other parts of Egypt, the reported temperatures ranged between 19 and $34^{\circ} \mathrm{C}$ (Kenawy et al., 1996; Abdel-Hamid et al., 2011c).

MacGregor (1927) recorded acidophile and alkalinophile mosquito larval species. The observed acidic to alkaline range of 5.0-8.7 for $C x$. pipiens, Cx. perexiguus and Oc. caspius is similar to 6.4-9.0 observed by Gad \& Salit (1972) in the Red Sea. Alkalinity was observed for $C s$. longiareolata (7.7-7.8) while the acidophilly of Cx. pusillus (5.0-5.5) may be due to the nature of its breeding habitats (cesspits and cesspools).

Based on water salinity, Kirkpatrick (1925) classified mosquito fauna of Egypt to purely fresh water breeders, purely salt water and more or less indifferent. It was observed that in general breeding habitats of the five species having fresh/brackish water (0.05-1.2\%) in agreement with the observation of Abdel-Hamid et al. (2011c) for Cx. pipiens and Cx. perexiguus in El-Ismailia. Gad et al. (1987) found that Oc. caspius inhabited

Table 2. Physico-chemical characteristics of the breeding water in El-Muqattam and Abu-Seir.

\begin{tabular}{|c|c|c|c|c|c|c|c|c|}
\hline Parameter & Locality & Spring & Spring canal & Cesspit & $\begin{array}{c}\text { Mean (SD) } \\
\text { Cesspool }\end{array}$ & $\begin{array}{l}\text { Drainag } \\
\text { e canal }\end{array}$ & $\begin{array}{l}\text { Irrigation } \\
\text { ditch }\end{array}$ & $\begin{array}{c}\text { Seepage } \\
\text { water }\end{array}$ \\
\hline Temperature $\left({ }^{\circ} \mathrm{C}\right)$ & $\begin{array}{l}\mathrm{M} \\
\mathrm{A}\end{array}$ & $\begin{array}{c}20.00 \\
(2.23)^{\mathrm{a}} \\
-\end{array}$ & $\begin{array}{c}20.00 \\
(2.24)^{\mathrm{a}} \\
-\end{array}$ & $\begin{array}{c}22.60 \\
(2.07)^{\mathrm{a}} \\
23.70 \\
(2.70)^{\mathrm{a}}\end{array}$ & $\begin{array}{l}23.70 \\
(2.00)^{\mathrm{b}} \\
26.60 \\
(3.58)^{\mathrm{a}}\end{array}$ & $\begin{array}{c}- \\
22.80 \\
(2.80)^{\mathrm{a}}\end{array}$ & $\begin{array}{c}- \\
26.50 \\
(3.39)^{\mathrm{a}}\end{array}$ & $\begin{array}{c}- \\
26.30 \\
(2.59)^{\mathrm{a}}\end{array}$ \\
\hline $\mathrm{pH}$ & $\begin{array}{l}\text { M } \\
\text { A }\end{array}$ & $\begin{array}{c}7.76 \\
(0.05)^{\mathrm{a}}\end{array}$ & $\begin{array}{c}7.76 \\
(0.05)^{\mathrm{a}}\end{array}$ & $\begin{array}{c}5.40 \\
(0.39)^{\mathrm{b}} \\
5.22 \\
(0.15)^{\mathrm{a}}\end{array}$ & $\begin{array}{c}5.30 \\
(0.14)^{\mathrm{b}} \\
5.32 \\
(0.19)^{\mathrm{a}}\end{array}$ & $\begin{array}{c}- \\
6.26 \\
(0.21)^{\mathrm{b}}\end{array}$ & $\begin{array}{c}- \\
6.90 \\
(0.07)^{\mathrm{c}}\end{array}$ & $\begin{array}{c}- \\
6.75 \\
(0.05)^{\mathrm{c}}\end{array}$ \\
\hline Salinity (\%) & $\begin{array}{l}\mathrm{M} \\
\mathrm{A}\end{array}$ & $\begin{array}{c}1.08 \\
(0.11)^{\mathrm{a}} \\
-\end{array}$ & $\begin{array}{c}1.25 \\
(0.11)^{\mathrm{a}} \\
-\end{array}$ & $\begin{array}{c}0.83 \\
(0.06)^{\mathrm{b}} \\
0.37 \\
(0.08)^{\mathrm{a}}\end{array}$ & $\begin{array}{c}0.69 \\
(0.08)^{\mathrm{c}} \\
0.17 \\
(0.06)^{\mathrm{b}}\end{array}$ & $\begin{array}{c}- \\
0.23 \\
(0.02)^{b}\end{array}$ & $\begin{array}{c}- \\
0.07 \\
(0.02)^{\mathrm{c}}\end{array}$ & $\begin{array}{c}- \\
2.10 \\
(0.22)^{d}\end{array}$ \\
\hline Turbidity (NTU) & $\begin{array}{l}\text { M } \\
\text { A }\end{array}$ & $\begin{array}{c}4.88 \\
(0.41)^{\mathrm{a}} \\
-\end{array}$ & $\begin{array}{c}4.36 \\
(0.79)^{\mathrm{a}} \\
-\end{array}$ & $\begin{array}{c}419.22 \\
(44.47)^{\mathrm{b}} \\
252.52 \\
(48.97)^{\mathrm{a}} \\
\end{array}$ & $\begin{array}{c}335.98 \\
(79.51)^{\mathrm{b}} \\
52.10 \\
(22.82)^{\mathrm{b}} \\
\end{array}$ & $\begin{array}{c}- \\
82.10 \\
(12.79)^{\mathrm{b}} \\
\end{array}$ & $\begin{array}{c}3.82 \\
(1.07)^{c}\end{array}$ & $\begin{array}{c}- \\
9.50 \\
(2.05)^{\mathrm{c}} \\
\end{array}$ \\
\hline DO (mg/L) & $\begin{array}{l}\mathrm{M} \\
\mathrm{A}\end{array}$ & $\begin{array}{c}7.19 \\
(0.28)^{\mathrm{a}} \\
-\end{array}$ & $\begin{array}{c}7.43 \\
(0.31)^{\mathrm{a}} \\
-\end{array}$ & $\begin{array}{c}2.92 \\
(0.11)^{\mathrm{b}} \\
2.46 \\
(0.61)^{\mathrm{a}}\end{array}$ & $\begin{array}{c}3.75 \\
(0.32)^{\mathrm{c}} \\
4.55 \\
(0.72)^{\mathrm{b}}\end{array}$ & $\begin{array}{c}- \\
3.75 \\
(0.47)^{\mathrm{c}}\end{array}$ & $\begin{array}{c}- \\
7.97 \\
(0.57)^{\mathrm{d}}\end{array}$ & $\begin{array}{c}- \\
3.05 \\
(0.64)^{\mathrm{ac}}\end{array}$ \\
\hline Nitrite (mg/L) & $\begin{array}{l}\text { M } \\
\text { A }\end{array}$ & $\begin{array}{c}0.20 \\
(0.23)^{\mathrm{a}} \\
-\end{array}$ & $\begin{array}{c}0.02 \\
(0.04)^{\mathrm{a}} \\
-\end{array}$ & $\begin{array}{l}0^{\mathrm{a}} \\
0^{\mathrm{a}}\end{array}$ & $\begin{array}{c}0^{\mathrm{a}} \\
\\
7.40 \\
(11.13)^{\mathrm{a}}\end{array}$ & $0^{-}$ & $0^{a}$ & $0^{\mathrm{a}}$ \\
\hline
\end{tabular}

M, El-Muqattam; A, Abu-Seir; DO, dissolved oxygen. a,b,c,dMeans followed by the same letters are not significantly different at (P>0.05) using ANOVA and Tukey's HSD test. 
Table 3. Comparative physico-chemical characteristics of the breeding water and associated mosquito larvae in the two localities.

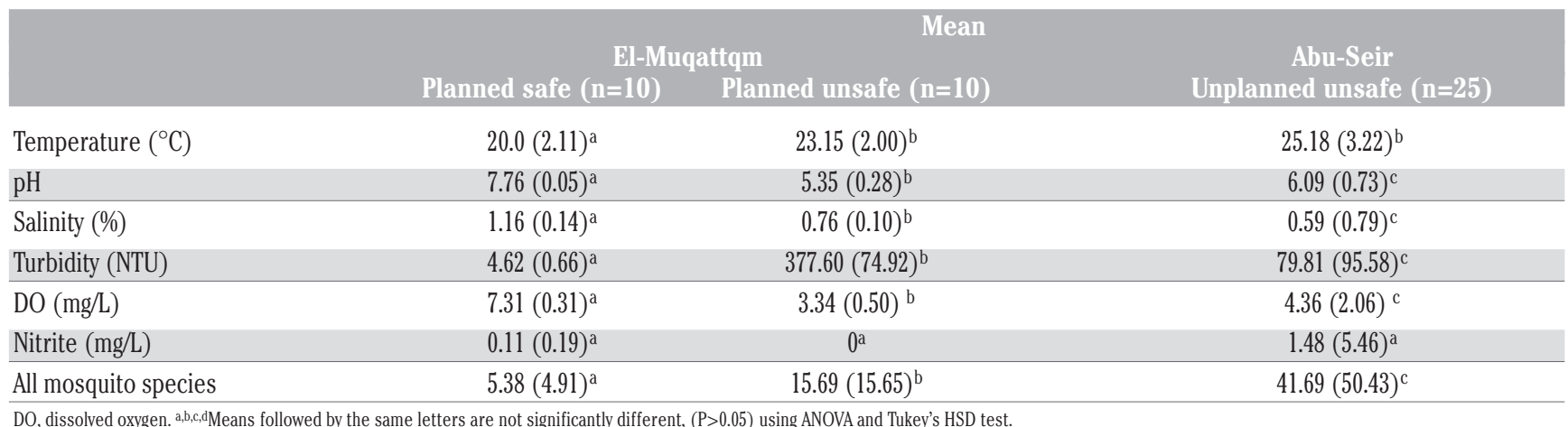

DO, dissolved oxygen. a,b,c,Means followed by the same letters are not significantly different, ( $P>0.05)$ using ANOVA and Tukey's HSD test.

Table 4. Multiple regression analysis for the effect of physico-chemical factors on larval densities of the two common mosquito species.

\begin{tabular}{|c|c|c|c|c|}
\hline \multirow[t]{3}{*}{ Factor } & \multicolumn{4}{|c|}{ The slope (regression coefficient) } \\
\hline & \multicolumn{2}{|c|}{ Cx. pipiens } & \multicolumn{2}{|c|}{$C x$. perexiguus } \\
\hline & El-Muqattam & Abu-Seir & El-Muqattam & Abu- Seir \\
\hline Temperature $\left({ }^{\circ} \mathrm{C}\right)$ & 1.35 & 1.23 & 1.02 & 0.26 \\
\hline $\mathrm{pH}$ & 9.46 & $83.43^{*}$ & 4.33 & $18.29^{*}$ \\
\hline Salinity & $-21.55^{*}$ & $-4.04^{*}$ & $-7.86^{*}$ & $-20.72^{*}$ \\
\hline Turbidity & -0.03 & -0.02 & -0.01 & -0.04 \\
\hline DO & $6.11^{*}$ & $30.61^{*}$ & 2.01 & $8.05^{*}$ \\
\hline Nitrite & $15.37^{*}$ & 0.25 & $21.17^{*}$ & 0.02 \\
\hline
\end{tabular}

DO, dissolved oxygen. " Significantly deviated from zero ( $\mathrm{P}<0.05, \mathrm{t}$-test).

breeding pools that were characterized by brackish water having high salt content.

It was reported (Sattler et al., 2005) that in turbid breeding sites culicine larvae were much more likely to be present, whereas Anopheles larvae were much more likely to be absent. This is supported by the wide ranges of turbidity (up to 485.2 NTU) reported for the three culex species: $C x$. pipiens, $C x$. perexiguus and $C x$. pusillus which indicates the tolerance of such species of highly turbid water. The preference of culicine mosquitoes for turbid water is coherent with their known breeding site preferences, as they breed successfully in rather polluted environments such as blocked drains and septic tanks (Chavasse et al., 1995). The low turbidity ranges reported for $O c$. Caspius (4.0-5.4 NTU) agrees with Seghal \& Pillai (1970) observation in Delhi where Anopheles and Culex were found to breed in highly turbid waters, in contrast to the three species of Aedes, which inhabited waters of low turbidity.

Sehgal \& Pillai (1970) observed that breeding waters of Aedes showed higher oxygen content than those of Culex and Anopheles. Similarly in this study, higher D0 range was reported for Oc. caspius $(6.9-8.7 \mathrm{mg} / \mathrm{L})$ than those for the other species.

Mosquitoes were found breeding in water free of nitrite or that having low content $(0.6 \mathrm{mg} / \mathrm{L})$ such as $C x$. pipiens, Oc. caspius and Cs. longiareolata or that having higher content $(25 \mathrm{mg} / \mathrm{L})$ such as $C x$. perexiguus and $C x$. pusillus. Although there are no available reports on nitrite contents for such species, however Salit et al. (1996) detected that $C x$. pipiens larvae in Kuwait State may tolerate various degrees of nitrite content as compared with other mosquito species. The higher nitrite content associated with higher larval density in A may be attributed to the use of fertilizers in the exiting fields. Sunish \& Reuben (2002) in India reported that the application of synthetic nitrogenous fertilizers to the rice fields was followed by a rise in concentration of ammonia nitrogen and a subsequent increase in nitrate nitrogen level in the rice field water, during which an increase in the density of larval instars was observed. Considering the compiled density of all mosquito species, there is an increasing occurrence from planned safe (M) to unplanned unsafe (A) habitats mainly due to turbidity and nitrite.

Sunish \& Reuben (2002) investigated the relationship of 13 abiotic variables with the abundance of $C x$. vishnui immatures in rice fields in south India. The results from the multiple regression models suggested that water temperature (+ve), D0 (-ve), ammonia nitrogen (-ve) and nitrate nitrogen $(+v e)$ to be the best predictor variables associated with the immature abundance. In this study, densities of both $C x$. pipiens and $C x$. perexiguus in the two localities had +ve relation with temperature $(\mathrm{P}>0.05)$ and $\mathrm{pH}(\mathrm{P}>0.05$ in $\mathrm{M}$ and $\mathrm{P}<0.05$ in $\mathrm{A})$ and $-\mathrm{ve}$ relation with salinity $(\mathrm{P}<0.05)$. Almost similar results were obtained by Kenawy et al. (1996) and Abdel-Hamid et al. (2011a) in other Egyptian Governorates. The two species were positively associated with D0 while it was reported that mosquito breeding is negatively correlates with D0 (Adebote et al., 2008) and chloride (Muturi et al., 2007, 2008). It was found that turbidity was negatively associated $(\mathrm{P}>0.05)$ and nitrite was positively associated with the abundance of the two species. Mala \& Irungu (2011) showed that the levels of nitrogen in different habitats are not affected by the presence of larvae although there was evidence for decreasing nitrogen levels with increasing larval densities.

In conclusion, based on the significant relations of the characteristic variables with the abundance of the two common larval species, salinity and DO can be considered as the predictor variables associated with the immature abundance. Considering altogether mosquitoes, there is an increasing presence from planned safe to unplanned unsafe habitats mainly due to turbidity and nitrite. The obtained results may be of help in designing and implementing control program based on environmental manipulation. 


\section{References}

ABDEL-HAMID Y.M., MOSTAFA A.A., ALLAM K.M., KENAWY M.A., 2011a - Mosquitoes (Diptera: Culicidae) in El- Gharbia Governorate, Egypt: their spatial distribution, abundance and factors affecting their breeding related to the situation of lymphatic filariasis. Egypt. Acad. J. Biol. Sci. 3: 9-16.

ABDEL-HAMID Y.M., SOLIMAN M.I., ALLAM K.M., 2009 - Spatial distribution and abundance of culicine mosquitoes in relation to the risk of filariasis transmission in El- Sharqiya Governorate, Egypt. Egypt. Acad. J. Biol. Sci. 1: 39-48.

ABDEL-HAMID Y.M., SOLIMAN M.I., KENAWY M.A., 2011b Geographical distribution and relative abundance of culicine mosquitoes in relation to transmission of lymphatic filariasis in ElMenoufia Governorate, Egypt. - J. Egypt. Soc. Parasitol. 41: 109-118.

ABDEL-HAMID Y.M., SOLIMAN M.I., KENAWY M.A., 2011c Mosquitoes (Diptera: Culicidae) in relation to the risk of disease transmission in El Ismailia Governorate, Egypt. - J. Egypt. Soc. Parasitol. 41: 347-356.

ADEBOTE D.A., ONIYE S.J., MUHAMMED Y.A., 2008 - Studies on mosquitoes breeding in rock pools on Inselbergs around Zaria, northern Nigeria. - J. Vector Borne Dis. 45: 21-28.

AMMAR S.E., KENAWY M.A., ABDEL-RAHMAN H.A., GAD A.M., HAMED A.F., 2012 - Ecology of the mosquito larvae in urban environments of Cairo Governorate, Egypt. - J. Egypt. Soc. Parasitol. 42:191-202.

APHA (AMERICAN PUBLIC HEALTH ASSOCIATION), 1998 - Standard methods for the examination of water and wastewater (Eaton A.D., Clesceri I.S., Greenberg A.E., editors), $20^{\text {th }}$ ed. - APHA, Washington, DC: 1325.

BAYOH M.N., LINDSAY S.W., 2003 - Effect of temperature on the development of the aquatic stages of Anopheles gambiae sensu stico (Diptera: Culicidae). - Bull. Entomol. Res. 93: 375-381.

BAYOH M.N., LINDSAY S.W., 2004 - Temperature-related duration of aquatic stages of the Afrotropical malaria vector mosquito Anopheles gambiae in the laboratory. - Med. Vet. Entomol. - 18: 174-179.

CHAVASSE D.C., LINES J.D., ICHIMORI K., MAJALA A.R., MINJAS J.N., MARIJANI J., 1995 - Mosquito control in Dar es Salaam. II. Impact of expanded polystyrene beads and pyriproxyfen treatment of breeding sites on Culex quinquefasciatus densities. - Med. Vet. Entomol. 9: 147-154.

DARWISH M., HOOGSTRAAL H., 1981 - Arboviruses infecting humans and lower animals in Egypt: a review of thirty years of research. J. Egypt. Public Health Assoc. 56: 1-112.

GAD A.M., EL-SAID S., HAMED M.S., SOLIMAN B.A., ABDEL-MOHSEN A., 1987 - Distribution and bionomics of Egyptian Cx. antennatus (Becker). - J. Egypt. Soc. Parasitol. 17: 207-221.

GAD A.M., SALIT A.M., 1972 - Mosquitoes of the Red Sea, Egypt. - J. Med. Entomol. 9: 581-582.

GIMNIG J.E., OMBOK M., KAMAU L., HAWLEY W.A., 2001 Characteristics of larval anophelinae (Diptera: Culicidae) habitats in western Kenya. - J. Med. Entomol. 38: 282-288.

HARB M., FARIS R., GAD A.M., HAFEZ 0.N., RAMZI R., BUCK A.A., 1993 - The resurgence of lymphatic filariasis in Nile Delta. - Bull. WHO. 71: 49-54.

HARBACH R.E., 1985 - Pictorial keys to the genera of mosquitoes, subgenera of Culex and the species of Culex (Culex) occurring in southwestern Asia and Egypt, with a note on the subgeneric placement of Culex deserticola (Diptera: Culicidae). - J. Mosq. Sys. 17: 83-107.
KENAWY M.A., RASHED S.S., TELEB S.S., 1996 - Population ecology of mosquito larvae (Diptera: Culicidae) in Sharkiya Governorate, Egypt. - J. Egypt. Ger. Soc. Zool. 21: 121-42.

KENAWY M.A., RASHED S.S., TELEB S.S., 1998 - Characterization of rice field mosquito habitats in Sharkia Governorate, Egypt. - J. Egypt. Soc. Parasitol. 28: 449-459.

KIRKPATRICK T.W., 1925 - The mosquitoes of Egypt. - Egyptian Government, Antimalaria Commission, Government Press, Cairo: 244.

MACGREGOR M.E., 1927- Mosquito surveys. - Welcome Bureau of Scientific Research, London: 282.

MALA A.0., IRUNGU L.W., 2011 - Factors influencing differential larval habitat productivity of Anopheles gambiae complex mosquitoes in a western Kenyan village. - J. Vector Borne Dis. 48: 52-57.

MEEGAN J.M., KHALIL G.M., HOOGSTRAAL H.H., ADHAM F.K., 1980 Experimental transmission and field isolation studies implicating Culex pipiens as a vector of Rift Valley Fever virus in Egypt. - Am. J. Trop. Med. Hyg. 29: 1405-1410.

MORSY T.A., KHALIL N.M., HABIB F.S., EL-LABOUDY N.A., 2003 Culicini mosquito larvae in Greater Cairo. - J. Egypt. Soc. Parasitol. 33: 717-732.

MUTURI E.J., MWANGANGI J.M., SHILILU J.I., JACOB B.G., MBOGO C., GITHURE J., et al., 2008 - Environmental factors associated with the distribution of Anopheles arabiensis and Culex quinquefasciatus in a rice agro-ecosystem in Mwea, Kenya. - J. Vector Ecol. 33: 56-63.

MUTURI E.J., SHILILU J.I., GU W., JACOB B.G., GITHURE J.I., NOVAK R.J., 2007 - Larval habitat dynamics and diversity of Culex mosquitoes in rice agro-ecosystem in Mwea, Kenya. - Am. J. Trop. Med. Hyg. 76: 95-102.

OVERGAARD H.J., TSUDA Y., SUWONKERD W., TAKAGI M., 2001 Characteristics of Anopheles minimus (Diptera: Culicidae) larval habitats in northern Thailand. - Environ. Entomol. 10: 134-141.

PIYARATNEA M.K., AMERASINGHEA F.P., AMERASINGHEA P.H., KONRADSENA F., 2005 - Physico-chemical characteristics of Anopheles culicifacies and Anopheles varuna breeding water in a dry zone stream in Sri Lanka. - J. Vect. Borne Dis. 42: 61-67

SALIT A.M., AL-TUBIAKH S.S., EL-FIKI S.A., ENAN 0.H., 1996 - Physical and chemical properties of different types of mosquito aquatic breeding places in Kuwait State. In: WILDEY K.B. (ed), Proceedings of the Second International Conference on Urban Pests. - ICUP, Edinburgh, UK: 185-193.

SATTLER M.A., MTASIWA D., KIAMA M., PREMJI Z., TANNER M., KILLEEN G.F., et al., 2005 - Habitat characterization and spatial distribution of Anopheles sp. mosquito larvae in Dar es Salaam (Tanzania) during an extended dry period. - Malaria J. 4: 4.

SEGHAL S., PILLAI M.K., 1970 - Preliminary studies on the chemical nature of mosquito breeding waters in Delhi. - Bull. WHO. 42: 647-650.

SUNISH I.P., REUBEN R., 2002 - Factors influencing the abundance of Japanese encephalitis vectors in rice fields in India - II. Biotic. - J. Med. Entomol. 16: 1-9.

TAWFICK M.K., 1990 - Mosquito fauna of certain urban and suburban areas of Cairo in relation to bancroftian filariasis. M.Sc. Thesis Ain Shams University, Cairo: 138.

WHITE G.B., 1974 - Anopheles gambiae complex and disease transmission in Africa. - Trans. Roy. Soc. Trop. Med. Hyg. 68: 278-301.

WHO (WORLD HEALTH ORGANIZATION), 1975 - Manual on practical entomology in malaria. Part (I). Vector bionomics and organization of anti-malaria activities. - WHO Division of Malaria and other Parasitic Diseases, WHO, Geneva: 160. 